
Nancy D. Epsky

\title{
Utility of essential oils for development of host- based lures for Xyleborus glabratus (Coleoptera: Curculionidae: Scolytinae), vector of laurel wilt
}

\author{
Essential oil lures for Xyleborus glabratus
}

https://doi.org/10.1515/chem-2018-0045

received December 18, 2017; accepted March 28, 2018.

\begin{abstract}
Redbay ambrosia beetle, Xyleborus glabratus, is native to Southeast Asia, but subsequent to introduction in Georgia in 2002, it has become a serious invasive pest in the USA, now established in nine southeastern states. Females vector Raffaelea lauricola, the fungus that causes laurel wilt, a lethal vascular disease of trees in the family Lauraceae. Laurel wilt has caused extensive mortality in native Persea species, including redbay (P. borbonia), swampbay (P. palustris), and silkbay (P. humilis). Avocado ( $P$. americana) is now impacted in Florida, and with continued spread, laurel wilt has potential to affect avocado and native Lauraceae in California, Mexico, and throughout the American tropics. Effective lures for detection and control of $X$. glabratus are critical to slow the spread of laurel wilt. No pheromones are known for this species; primary attractants are volatile terpenoids emitted from host Lauraceae. This report provides a concise summary of the chemical ecology of $X$. glabratus, highlighting research to identify kairomones used by females for host location. It summarizes development of essential oil lures for pest detection, including discussions of the initial use of phoebe and manuka oil lures, the
\end{abstract}

\footnotetext{
*Corresponding author: Paul E. Kendra, USDA-ARS, Subtropical Horticulture Research Station, 13601 Old Cutler Road, Miami, FL 33158 USA, E-mail: paul.kendra@ars.usda.gov

Wayne S. Montgomery, Jerome Niogret, Nurhayat Tabanca, David Owens, Nancy D. Epsky: USDA-ARS, Subtropical Horticulture Research Station, 13601 Old Cutler Road, Miami, FL 33158 USA Jerome Niogret: Current address: Niogret Ecology Consulting LLC, 2980 SW 25th Street, Miami, FL 33133 USA

David Owens: Current address: University of Delaware, Carvel Research and Education Center, 16483 County Seat Highway, Georgetown, DE 19947 USA
}

current cubeb oil lure, and a newly-developed distilled oil lure enriched in (-)- $\alpha$-copaene.

Keywords: redbay ambrosia beetle; $\alpha$-copaene;

kairomone; sesquiterpene; enantiomer.

\section{Introduction}

The redbay ambrosia beetle, Xyleborus glabratus Eichhoff (Coleoptera: Curculionidae: Scolytinae), is a wood-borer endemic to Southeast Asia. Although benign in its native range [1], the beetle has become a serious invasive pest of agricultural and forest ecosystems in the USA. Xyleborus glabratus females are the primary vectors of a fungal pathogen that causes laurel wilt, a lethal vascular disease of American trees in the family Lauraceae [2,3]. During gallery excavation, beetles introduce spores of several symbiotic fungi, including Raffaelea lauricola T. C. Harr., Fraedrich \& Aghayeva, the etiologic agent of laurel wilt [4,5]. Presence of $R$. lauricola in susceptible hosts triggers secretion of gels and formation of parenchymal tyloses within xylem vessels [6,7]. This defensive response impedes water transport, which leads to systemic wilt and ultimately death of infected trees.

First detected in the USA during 2002 near Savannah, Georgia, X. glabratus has since invaded eight additional southeastern states [8], where incidence of laurel wilt has escalated to epidemic proportions (reviewed in [9-11]). Ecological impact has been most severe on native Persea populations, with extensive mortality of redbay [P. borbonia (L.) Spreng.], swampbay [P. palustris (Raf.) Sarg.], and silkbay ( $P$. humilis Nash). Currently, commercial avocado (P. americana Mill.) is impacted in southern Florida [7,12], and with continued spread, laurel wilt may threaten 
avocado production in Mexico and California. In addition, numerous trees and woody shrubs within the Lauraceae are potentially at risk in the USA, Mexico, and throughout the American tropics. An effective lure for early detection of $X$. glabratus is critical for development of management programs to slow the spread of laurel wilt.

\section{Chemical Ecology of $X$. glabratus}

Like other ambrosia beetles within the tribe Xyleborini, $X$. glabratus is known to have extensive inbreeding, haplodiploid sex determination, and a sex ratio highly skewed toward females [13]. Pheromones are not used by these species, since females typically mate with their flightless male siblings before dispersing from natal trees. However, females of $X$. glabratus are atypical with respect to their hostseeking behaviors. The majority of xyleborine beetles are broad generalists that target stress-weakened or dying trees [14], but $X$. glabratus can function ecologically as a primary colonizer, attacking live healthy trees [2]. Xyleborus glabratus is not attracted to ethanol [3,15], a volatile indicative of tree decay, which is the standard lure used for general detection and monitoring of ambrosia beetles [16]. Furthermore, $X$. glabratus is not a host generalist in the USA, but appears to be restricted to members of the Lauraceae $[10,17]$.

Given the absence of species-specific pheromones for $X$. glabratus, and lack of attraction to ethanol, research on lure development has focused on the kairomones used by $X$. glabratus for host location. The current hypothesis is that dispersing females detect, via antennal olfactory receptors, a mixture of volatile terpenoids characteristic of the Lauraceae (i.e., a signature host bouquet) [18-23]. A comprehensive comparative study [17] examined nine species within the Lauraceae (including avocado cultivars representative of each of the three botanical races) to determine in-flight attraction of $X$. glabratus as related to phytochemical emissions from host wood. Emissions of $\alpha$-copaene, $\alpha$-cubebene, $\alpha$-humulene, and calamenene (all sesquiterpene hydrocarbons) were positively correlated with attraction to Lauraceae [17]. Of these compounds, $\alpha$-copaene and $\alpha$-humulene had been correlated previously with attraction to essential oil lures and to wood from lychee (Litchi chinensis Sonn.; Sapindaceae) [19]. Lychee is not a host of X. glabratus, but particular cultivars are highly attractive to females due to sesquiterpene emissions similar to those of the Lauraceae [19,22,24]. In addition, independent research identified eucalyptol (1,8 cineole; a monoterpene ether) as another host-based attractant [25]. For all these terpenoid compounds, olfactory chemoreception has been confirmed in female $X$. glabratus using dissected antennae and electrophysiological recording techniques $[17,26]$.

\section{Field Lures}

Although identification of specific attractant chemicals has been useful for understanding the chemical ecology and host-seeking behaviors of $X$. glabratus, production of field lures using synthetic sesquiterpenes may not be feasible. Many sesquiterpenes, particularly $\alpha$-copaene, are expensive, difficult to synthesize, and not readily available in quantities sufficient for trap deployment [27]. Consequently, development of economical lures has relied on the use of plant-derived essential oils naturally high in attractive sesquiterpenes.

\subsection{Manuka and Phoebe Oils}

Research by Crook et al. [28] on host-based semiochemicals for the emerald ash borer, Agrilus planipennis Fairmaire (Coleoptera: Buprestidae), identified two essential oils attractive to this wood-boring beetle: manuka oil (extracted from Leptospermum scoparium Forst. \& Forst.; Myrtaceae) and phoebe oil (from Phoebe porosa Mez; Lauraceae). When initially tested in Georgia and South Carolina, these two oils were also found to be attractive baits for trapping $X$. glabratus [18]. However, when commercial manuka and phoebe oil lures were evaluated in Florida in 2009-2010, both were found to be fairly non-specific, capturing a variety of non-target Scolytinae [21,24]. More importantly, the manuka oil lures were not competitive with host Persea wood (Figure 1A), which had higher content of $\alpha$-copaene and other sesquiterpene constituents [19]. In addition, manuka oil lures had a field life of only 2-3 weeks (Figure 1C) due to rapid (exponential) loss of sesquiterpenes when exposed to field conditions [21]. In contrast, phoebe oil lures had substantially higher content of $\alpha$-copaene [19], were competitive with host wood (Figure 1A), captured significantly more $X$. glabratus than manuka oil lures (Figure 1B), and despite rapid loss of terpenoids initially, continued to release low levels of attractive sesquiterpenes for at least 10 weeks (Figure 1C). Unfortunately, shortly after completion of the field studies by Kendra et al. [21], phoebe oil lures could no longer be produced commercially due to a limited supply of source trees in Brazil. Therefore, the suboptimal manuka oil lure became the standard for detection of $X$. glabratus in the USA. 

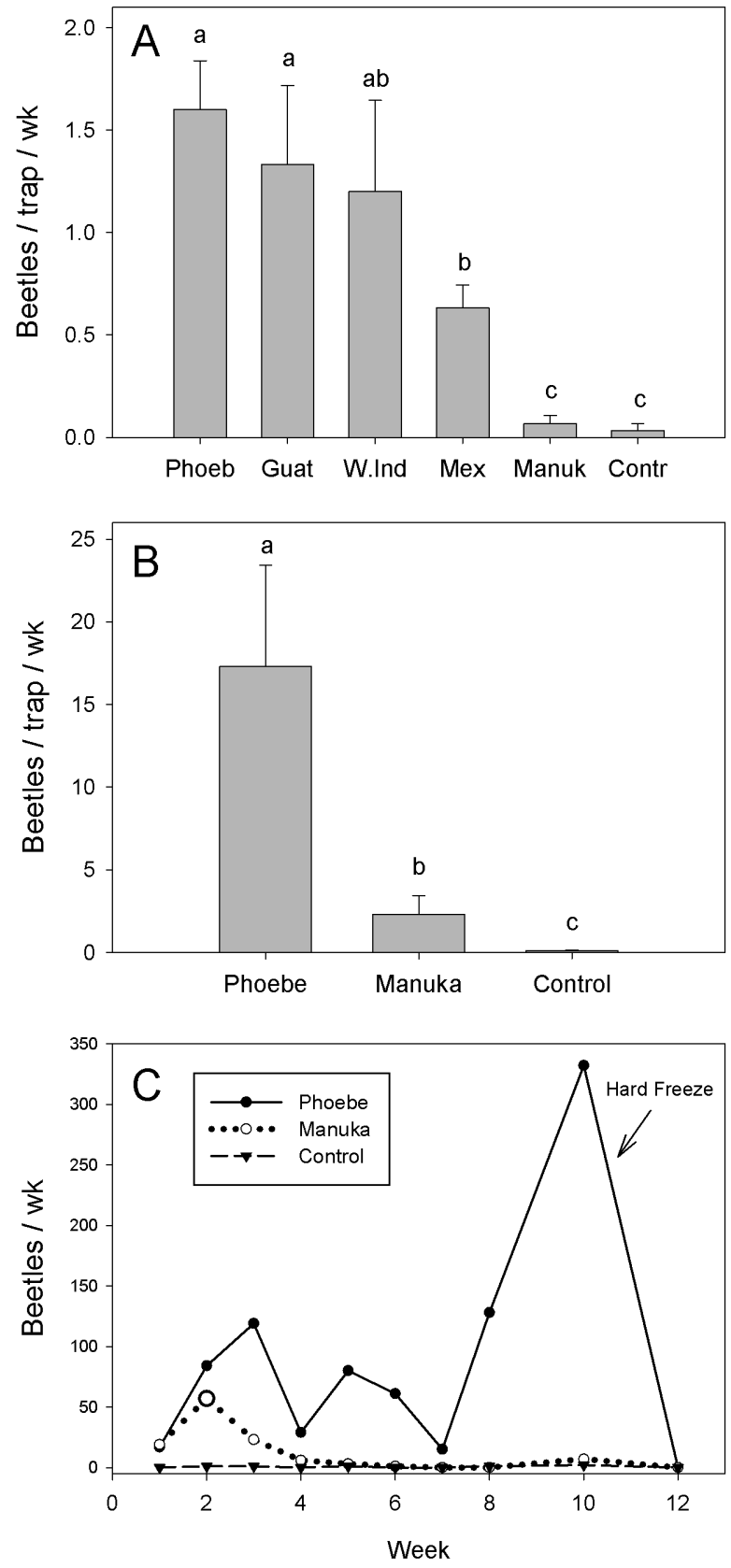

Figure 1: Captures of female Xyleborus glabratus in field trials conducted in Florida, USA. (A) Mean ( \pm SE) captures in an 8-wk test (Alachua County, FL) with commercial phoebe oil lure (Phoeb), commercial manuka oil lure (Manuk), wood bolts of three cultivars of avocado: 'Brooks Late', Guatemalan race (Guat); 'Simmonds', West Indian race (W. Ind); 'Seedless Mexican', Mexican race (Mex), and an unbaited control (Contr); adapted from [19]. (B) Mean ( \pm SE) captures and (C) summed weekly captures obtained in a 12-wk test (Highlands County, FL) with commercial oil lures and an unbaited control; adapted from [21]. For both tests, $\mathrm{N}=5$ traps per treatment; bars topped with the same letter are not significantly different.

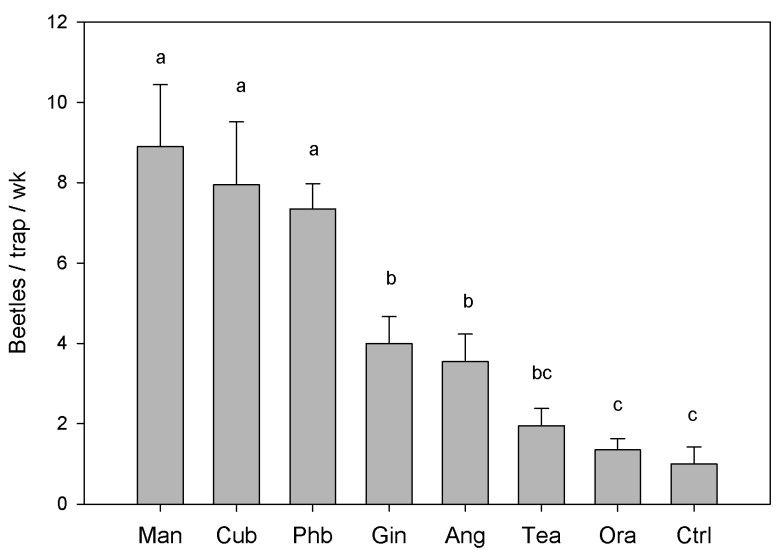

Figure 2: Mean $( \pm \mathrm{SE})$ captures of female Xyleborus glabratus with seven essential oils deployed in a 4-wk field test conducted in Highlands County, FL, USA. Treatments consisted of manuka (Man), cubeb (Cub), phoebe (Phb), ginger root (Gin), angelica seed (Ang), tea tree (Tea), Valencia orange (Ora) oils, and an unbaited control trap (Ctrl); $\mathrm{N}=5$ traps per treatment. A membrane-based dispenser was used to prepare the lures, and each lure was loaded with $5 \mathrm{ml}$ of neat oil. Bars topped with the same letter are not significantly different; adapted from [9].

\subsection{Cubeb Oil}

The shortcomings of manuka oil lures prompted research to evaluate other essential oils as potential alternatives. Initial field tests in 2012 compared captures of X. glabratus among seven essential oils, including manuka and phoebe oils [9,15]. Five new oils - cubeb, ginger root, angelica seed, tea tree, and Valencia orange oils - were chosen based on (i) their sesquiterpene content, which included constituents that were correlated with captures of $X$. glabratus in previous tests $[19,21]$, and (ii) their attractiveness to males of the Mediterranean fruit fly, Ceratitis capitata Wied. (Diptera: Tephritidae), another pest attracted to substrates high in $\alpha$-copaene [27,29]. Of the new oils evaluated, ginger root and angelica seed oils were moderately attractive, but whole cubeb oil (obtained from berries of tailed pepper, Piper cubeba L.; Piperaceae) was identified as a strong new attractant for female $X$. glabratus (Figure 2) [9].

Subsequent studies in 2013 with a commercial cubeb lure (proprietary plastic bubble containing a distilled oil product enriched in sesquiterpenes; Synergy Semiochemicals Corp., Burnaby, BC, Canada) found that this product captured significantly more $X$. glabratus than the commercial manuka oil lure in field trials $[15,30]$. Further evaluations [31] indicated that the cubeb oil lure was also better than the phoebe oil lure (Figure 3A) and had a field life of at least 12 weeks (Figure 3B). 



Figure 3: Captures of female Xyleborus glabratus in a 12-wk field test conducted in Highlands County, FL, USA. (A) Mean ( \pm SE) captures and (B) summed weekly captures obtained with commercial oil lures and an unbaited control; $\mathrm{N}=5$ traps per treatment. Bars topped with the same letter are not significantly different; adapted from [31].

Temporal analysis of cubeb lure emissions revealed that its superior longevity was due to extended low release of sesquiterpenes, primarily $\alpha$-copaene (Figure 4A) and $\alpha$-cubebene (Figure 4B) [31]. The bubble dispenser used for the new cubeb lure has a much lower surface areato-volume ratio than the flat rectangular design of the manuka oil lure. This difference, coupled with a thicker release membrane, has resulted in a better delivery system for sustained release of sesquiterpene attractants.

\subsection{Copaiba Oil and Enriched $\alpha$-Copaene Oil}

With acceptance of the cubeb oil lure as the new standard for detection of $X$. glabratus, research (in collaboration with Synergy Semiochemicals Corp.) focused on elucidation of the attractive components found in cubeb oil. Since
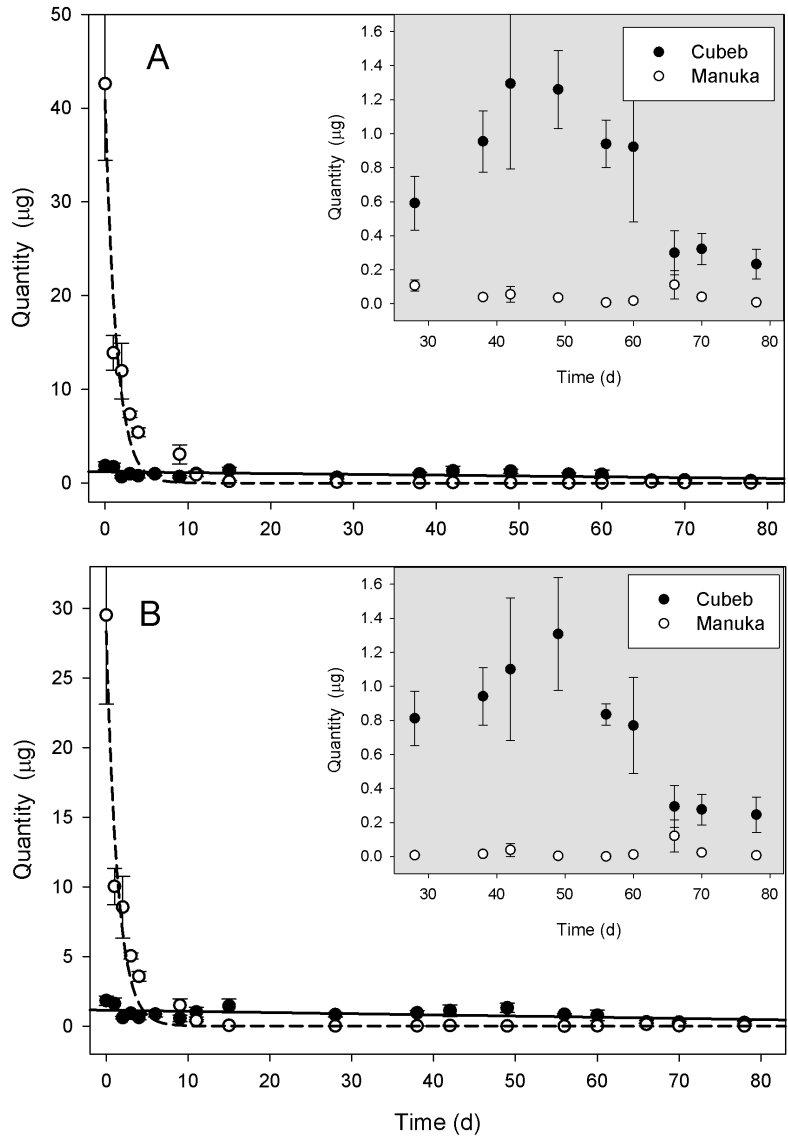

Figure 4: Emissions of (A) $\alpha$-copaene and (B) $\alpha$-cubebene quantified over time from commercial oil lures field-deployed for $12 \mathrm{wk}$ in Miami-Dade County, FL, USA. Inset enhances the scale for emissions beginning at $4 \mathrm{wk}$, the point at which manuka lures lost efficacy for attraction of $X$. glabratus in field tests. Volatiles were isolated by super-Q collection, analyzed by GC-MS, and identified by comparison of Kovats retention index with synthetic chemical; adapted from [31].

this essential oil is composed of a complex mixture of terpenoids, hydrodistillation was used to separate whole cubeb oil into multiple fractions, based on boiling point of the terpenoid constituents. These fractions were then evaluated in electroantennographic analyses and binarychoice bioassays to quantify olfactory and behavioral responses, respectively. Results indicated that fractions with high $\alpha$-copaene and $\alpha$-cubebene content were the most bioactive for female $X$. glabratus [32], supporting previous hypotheses regarding the importance of these kairomones [15,17-23,31]. Based on this observation, two additional essential oil products were evaluated, both formulated in slow-release bubble dispensers. The first lure contained whole copaiba oil (extracted from species of Copaifera L.; Leguminoseae), an essential oil lacking in $\alpha$-cubebene, but with twice as much $\alpha$-copaene as whole 

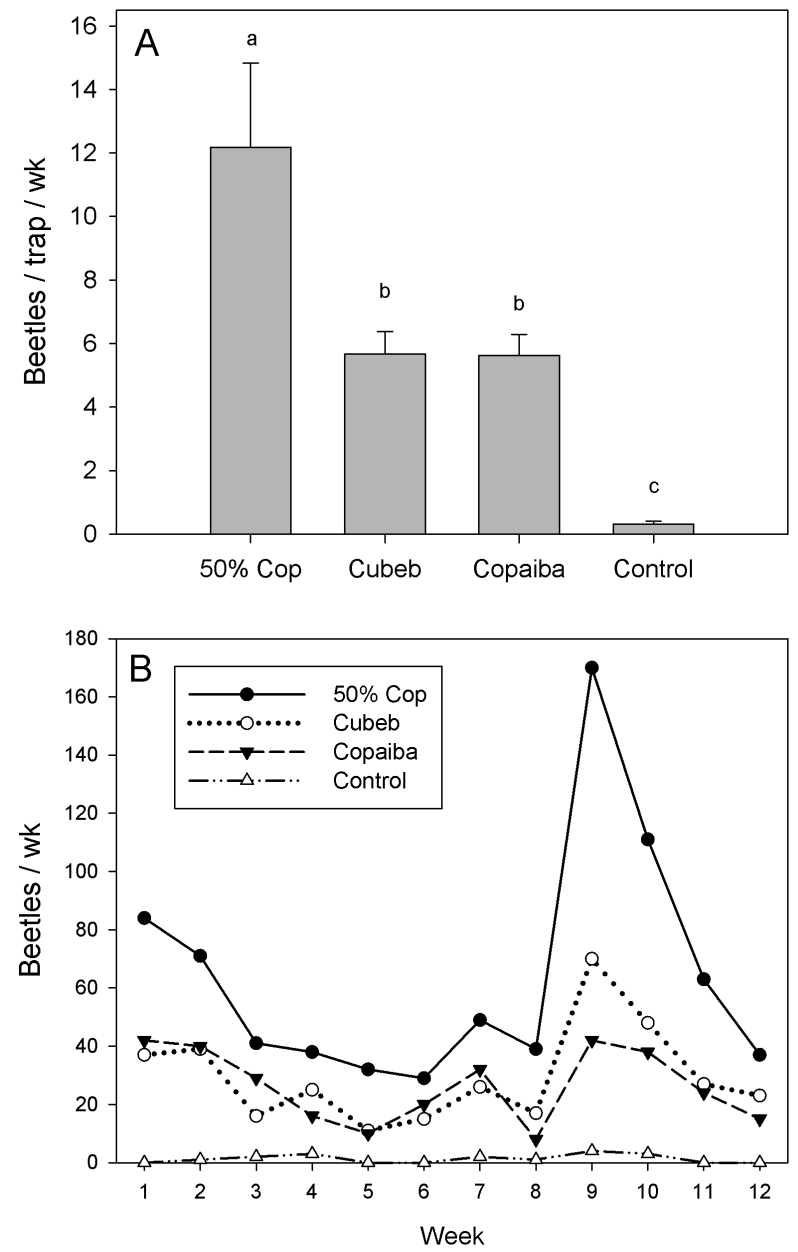

Figure 5: Captures of female Xyleborus glabratus in a 12-wk field test conducted in Highlands County, FL, USA. (A) Mean ( \pm SE) captures and (B) summed weekly captures obtained with commercial cubeb oil lure, prototype copaiba oil lure, prototype $50 \% \alpha$-copaene lure ( $50 \%$ cop), and an unbaited control trap; $\mathrm{N}=5$ traps per treatment. Bars topped with the same letter are not significantly different; adapted from [32].

cubeb oil [32]. In two field trials, the prototype copaiba oil lure captured equal numbers of $X$. glabratus as the commercial cubeb oil lure (Figure 5A) [32].

The second prototype lure contained a proprietary essential oil product that was distilled to achieve 50 percent $\alpha$-copaene content. In multiple field tests, this enriched $\alpha$-copaene lure captured significantly more $X$. glabratus than the cubeb oil lure (Figure 5A), and also displayed field longevity of at least three months (Figure 5B) $[32,33]$. This research confirmed the role of $\alpha$-copaene as a primary host-location cue, and identified the $50 \%$ $\alpha$-copaene lure (now available commercially) as an improved tool for more sensitive detection of $X$. glabratus than that currently provided by the cubeb oil lure. In addition, recent research [34] documented that the enriched $\alpha$-copaene lure is also attractive to Euwallacea nr. fornicatus, an invasive ambrosia beetle that vectors the fungus responsible for Fusarium dieback disease in avocado and numerous other trees in the USA [35-37].

\subsection{Chemical Analysis of the Enriched $\alpha$-Copaene Oil}

We previously identified the chemical composition of the commercial $\alpha$-copaene lure by GC-FID and GC-MS using an apolar column, DB-5MS [38]. Lure constituents were almost entirely sesquiterpene hydrocarbons ( $98.7 \%$ ), with only one oxygenated sesquiterpene, caryophyllene oxide $(\sim 1.3 \%)$. The predominant components were $\alpha$-copaene $(\sim 51.3 \%), \beta$-caryophyllene $(\sim 22.5 \%), \delta$-cadinene $(\sim 10 \%)$ and $\alpha$-humulene $(\sim 4.2 \%)$; minor components included $\alpha$-cubebene, $\beta$-cubebene, $\beta$-elemene, alloaromadendrene, $\gamma$-muurolene and $\alpha$-muurolene. We also conducted chiral separation of the $\alpha$-copaene component, using an Rt$\beta$ Dex $_{\text {se }}$ column [38]. This separation indicated that the lure contained (+)- $\alpha$-copaene $(0.1 \%)$ and (-)- $\alpha$-copaene (99.9\%). In nature, (-)- $\alpha$-copaene occurs as the more prevalent enantiomer [39,40] and our results were in good agreement. Enantiomers often show different pharmacological and biological activity, underlying the importance of accurate separation and identification. Our analysis of the lure contents indicated that $X$. glabratus is preferentially attracted to (-)- $\alpha$-copaene [38], whereas C. capitata is more responsive to the positive enantiomer [27]. Development of effective enantiomeric analysis methods can help not only in understanding the biological functions, but also in exploring new applications.

\section{Conclusions}

Research over the past few years has been successful in terms of (i) gaining a better understanding of the semiochemicals used by female $X$. glabratus for host location, and (ii) improving the efficacy and field longevity of host-based lures for detection of this pest. However, host location and acceptance by an ambrosia beetle is a multistep process that requires perception and interpretation of a series of cues presented in proper sequence and in proper context [17]. Host volatile terpenoids are chemical cues that direct only the initial steps of that process. Further improvement of pest detection systems for X. glabratus 
should be possible through novel combinations of appropriate attractant cues. Experimental research is just beginning to evaluate multi-component lures composed of several known ambrosia beetle attractants. The essential oil enriched in the negative enantiomer of $\alpha$-copaene is the best single lure identified to date for dispersing $X$. glabratus, but efficacy of this kairomone-based lure may be increased when coupled with food-based fungal odors [41,42] or with volatile spiroketals (e.g. conophthorin, chalcogran [43-45]). In conjunction with lure evaluations, research is needed for improvement of trap design. With essential oil lures alone, capture efficiency of $X$. glabratus is low with our current detection systems [21,31,32]; this may be increased with appropriate visual cues, including optimization of trap color, shape and diameter [46], and potentially with incorporation of light emitting diodes of specific wavelengths [45].

Declaration: No conflicts of interest are reported by the authors.

Acknowledgments: The authors are grateful to Hilary Swain and Mark Deyrup for providing laboratory space, lodging, and access to field sites at Archbold Biological Station (Lake Placid, FL), where much of this research was conducted; and to David Wakarchuk (Synergy Semiochemicals Corp., Burnaby, BC, Canada) for providing lures for laboratory analyses and field evaluations. We also acknowledge David Hall (USDA-ARS, Ft. Pierce, FL) and David Jenkins (South Carolina Forestry Commission, Columbia, SC) for critical reviews of the manuscript. Studies were funded in part by the USDA-ARS National Plant Disease Recovery System and the Florida Avocado Administrative Committee. Mention of a proprietary product does not constitute an endorsement by the USDAARS.

\section{References}

[1] Beaver R.A., Liu L.Y., An annotated synopsis of Taiwanese bark and ambrosia beetles, with new synonymy, new combinations and new records (Coleoptera: Curculionidae: Scolytinae). Zootaxa, 2010, 2602, 1-47.

[2] Fraedrich S.W., Harrington T.C., Rabaglia R.J., Ulyshen M.D., Mayfield III A.E., Hanula J.L., Eickwort J.M., Miller D.R., A fungal symbiont of the redbay ambrosia beetle causes a lethal wilt in redbay and other Lauraceae in the southeastern USA. Plant Dis., 2008, 92, 215-224.

[3] Hanula J.L., Mayfield III A.E., Fraedrich S.W., Rabaglia R.J., Biology and host associations of redbay ambrosia beetle, Xyleborus glabratus (Coleoptera: Curculionidae: Scolytinae), exotic vector of laurel wilt killing redbay (Persea borbonia) trees in the southeastern United States. J. Econ. Entomol., 2008, 101, 1276-1286.

[4] Harrington T.C., Fraedrich S.W., Aghayeva D.N., Raffaelea lauricola, a new ambrosia beetle symbiont and pathogen on the Lauraceae. Mycotaxon, 2008, 104, 399-404.

[5] Harrington T.C., Aghayeva D.N., Fraedrich S.W., New combinations of Raffaelea, Ambrosiella, and Hyalorhinocladiella, and four new species from the redbay ambrosia beetle, Xyleborus glabratus. Mycotaxon, 2010, 111, 337-361.

[6] Inch S., Ploetz R., Held B., Blanchette R., Histological and anatomical responses in avocado, Persea americana, induced by the vascular wilt pathogen, Raffaelea lauricola. Botany, 2012, 90, 627-635.

[7] Ploetz R.C., Pérez-Martínez J.M., Smith J.A., Hughes M., Dreaden T.J., Inch S.A., Fu Y., Responses of avocado to laurel wilt, caused by Raffaelea lauricola. Plant Pathol., 2012, 61, 801808.

[8] USDA Forest Service, Southern Regional Extension Forestry. Distribution of Counties with Laurel Wilt Disease as of April 14, 2017. <http://southernforesthealth.net/fungi/laurel-wilt/ distributionmap $>$

[9] Kendra P.E., Montgomery W.S., Niogret J., Epsky N.D., An uncertain future for American Lauraceae: A lethal threat from redbay ambrosia beetle and laurel wilt disease (A review). Am. J. Plant Sci., 2013, 4, 727-738.

[10] Hughes M.A., Smith J.A., Ploetz R.C., Kendra P.E., Mayfield A.E., Hanula J.L., Hulcr J., Stelinski L.L., Cameron S., Riggins J.J., Carrillo D., Rabaglia R., Eickwort J., Pernas T., Recovery plan for laurel wilt on redbay and other forest species caused by Raffaelea lauricola and disseminated by Xyleborus glabratus. Plant Health Prog., 2015, 16, 173-210.

[11] Ploetz R.C., Kendra P.E., Choudhury R.A., Rollins J.A., Campbell A., Garrett K., Hughes M., Dreaden T., Laurel wilt in natural and agricultural ecosystems: Understanding the drivers and scales of complex pathosystems. Forests, 2017, 8, 48.

[12] Ploetz R.C., Hughes M.A., Kendra P.E., Fraedrich S.W., Carrillo D., Stelinski L.L., Hulcr J., Mayfield A.E., Dreaden T.L., Crane J.H., Evans E.A., Schaffer B.A., Rollins J.A., Recovery plan for laurel wilt of avocado, caused by Raffaelea lauricola. Plant Health Prog., 2017, 18, 51-77.

[13] Rabaglia R.J., Dole S.A., Cognato A.I., Review of American Xyleborina (Coleoptera: Curculionidae: Scolytinae) occurring north of Mexico, with an illustrated key. Ann. Entomol. Soc. Am., 2006, 99, 1034-1056.

[14] Hulcr J., Mogia M., Isua B., Novotny V., Host specificity of ambrosia and bark beetles (Col., Curculionidae: Scolytinae and Platypodinae) in a New Guinea rain forest. Ecol. Entomol., 2007, 32, 762-772.

[15] Kendra P.E., Montgomery W.S., Niogret J., Schnell E.Q., Deyrup M.A., Epsky N.D., Evaluation of seven essential oils identifies cubeb oil as most effective attractant for detection of Xyleborus glabratus. J. Pest Sci., 2014, 87, 681-689.

[16] Miller D.R., Rabaglia R.J., Ethanol and (-)- $\alpha$-pinene: Attractant kairomones for bark and ambrosia beetles in the southeastern U.S. J. Chem. Ecol., 2009, 35, 435-448.

[17] Kendra P.E., Montgomery W.S., Niogret J., Pruett G.E., Mayfield III A.E., MacKenzie M., Deyrup M.A., Bauchan G.R., Ploetz R.C., Epsky N.D., North American Lauraceae: Terpenoid emissions, 
relative attraction and boring preferences of redbay ambrosia beetle, Xyleborus glabratus (Coleoptera: Curculionidae: Scolytinae). PLoS ONE, 2014, 9, e102086.

[18] Hanula J.L., Sullivan B., Manuka oil and phoebe oil are attractive baits for Xyleborus glabratus (Coleoptera: Curculionidae: Scolytinae), the vector of laurel wilt. Environ. Entomol., 2008, 37, 1403-1409.

[19] Kendra P.E., Montgomery W.S., Niogret J., Peña J.E., Capinera J.L., Brar G., Epsky N.D., Heath R.R., Attraction of the redbay ambrosia beetle, Xyleborus glabratus, to avocado, lychee, and essential oil lures. J. Chem. Ecol., 2011, 37, 932-942.

[20] Niogret J., Kendra P.E., Epsky N.D., Heath R.R., Comparative analysis of terpenoid emissions from Florida host trees of the redbay ambrosia beetle, Xyleborus glabratus (Coleoptera: Curculionidae: Scolytinae). Florida Entomol., 2011, 94, 10101017.

[21] Kendra P.E., Niogret J., Montgomery W.S., Sanchez J.S., Deyrup M.A., Pruett G.E., Ploetz R.C., Epsky N.D., Heath R.R., Temporal analysis of sesquiterpene emissions from manuka and phoebe oil lures and efficacy for attraction of Xyleborus glabratus (Coleoptera: Curculionidae: Scolytinae). J. Econ. Entomol., 2012, 105, 659-669.

[22] Kendra P.E., Ploetz R.C., Montgomery W.S., Niogret J., Peña J.E., Brar G.S., Epsky N.D., Evaluation of Litchi chinensis for host status to Xyleborus glabratus (Coleoptera: Curculionidae: Scolytinae) and susceptibility to laurel wilt disease. Florida Entomol., 2013, 96, 1442-1453.

[23] Niogret J., Epsky N.D., Schnell R.J., Boza E.J., Kendra P.E., Heath R.R., Terpenoid variations within and among half-sibling avocado trees, Persea americana Mill. (Lauraceae). PLoS ONE, 2013, 8, e73601.

[24] Kendra P.E., Sanchez J.S., Montgomery W.S., Okins K.E., Niogret J., Peña J.E., Epsky N.D., Heath R.R., Diversity of Scolytinae (Coleoptera: Curculionidae) attracted to avocado, lychee, and essential oil lures. Florida Entomol., 2011, 94, 123130.

[25] Kuhns E.H., Martini X., Tribuiani Y., Coy M., Gibbard C., Peña J., Hulcr J., Stelinski L.L., Eucalyptol is an attractant of the redbay ambrosia beetle, Xyleborus glabratus. J. Chem. Ecol., 2014, 40, 355-362.

[26] Kendra P.E., Montgomery W.S., Niogret J., Deyrup M.A., Guillén L., Epsky N.D., Xyleborus glabratus, X. affinis, and $X$. ferrugineus (Coleoptera: Curculionidae: Scolytinae): Electroantennogram responses to host-based attractants and temporal patterns in host-seeking flight. Environ. Entomol., 2012, 41, 1597-1605.

[27] Flath R.A., Cunningham R.T., Mon T.R., John J.O., Male lures for Mediterranean fruit fly (Ceratitis capitata Wied.): structural analogs of $\alpha$-copaene. J. Chem. Ecol., 1994, 20, 2595-2609.

[28] Crook D.J., Khirimian A., Francese J.A., Fraser I., Poland T.M., Sawyer A.J., Mastro V.C., Development of a host-based semiochemical lure for trapping emerald ash borer, Agrilus planipennis (Coleoptera: Buprestidae). Environ. Entomol., 2008, 37, 356-365.

[29] Niogret J., Montgomery W.S., Kendra P.E., Heath R.R., Epsky N.D., Attraction and electroantennogram responses of male Mediterranean fruit fly (Diptera: Tephritidae) to volatile chemicals from Persea, Litchi, and Ficus wood. J. Chem. Ecol., 2011, 37, 483-491.
[30] Hanula J.L., Sullivan B.T., Wakarchuk D., Variation in manuka oil lure efficacy for capturing Xyleborus glabratus (Coleoptera: Curculionidae: Scolytinae), and cubeb oil as an alternative attractant. Environ. Entomol., 2013, 42, 333-340.

[31] Kendra P.E., Niogret J., Montgomery W.S., Deyrup M.A., Epsky N.D., Cubeb oil lures: Terpenoid emissions, trapping efficacy, and longevity for attraction of redbay ambrosia beetle (Coleoptera: Curculionidae: Scolytinae). J. Econ. Entomol., 2015,108, 350-361.

[32] Kendra P.E., Montgomery W.S., Deyrup M.A., Wakarchuk D., Improved lure for redbay ambrosia beetle developed by enrichment of $\alpha$-copaene content. J. Pest Sci., 2016, 89, 427 438.

[33] Kendra P.E., Montgomery W.S., Schnell E.Q., Deyrup M.A., Epsky N.D., Efficacy of $\alpha$-copaene, cubeb, and eucalyptol lures for detection of redbay ambrosia beetle (Coleoptera: Curculionidae: Scolytinae). J. Econ. Entomol., 2016, 109, 24282435.

[34] Kendra P.E., Owens D., Montgomery W.S., Narvaez T.I., Bauchan G.R., Schnell E.Q., Tabanca N., Carrillo D., $\alpha$-Copaene is an attractant, synergistic with quercivorol, for improved detection of Euwallacea nr. fornicatus (Coleoptera: Curculionidae: Scolytinae). PLoS One, 2017, 12, e0179416.

[35] Carrillo D., Cruz L.F., Kendra P.E., Narvaez T.I., Montgomery W.S., Monterroso A., DeGrave C., Copperband M.F., Distribution, pest status and fungal associates of Euwallacea nr. fornicatus in Florida avocado groves. Insects, 2016, 7, 55.

[36] Eskalen A., Fusarium dieback / PSHB \& KSHB distribution map. University of California, Riverside, 2016. <http://eskalenlab. ucr.edu/distribution.html>

[37] Owens D., Cruz L.F., Montgomery W.S., Narvaez T.I., Schnell E.Q., Tabanca N., Duncan R.E., Carrillo D., Kendra P.E., Host range expansion and increasing damage potential of Euwallacea nr. fornicatus (Coleoptera: Curculionidae) in Florida. Florida Entomol., 2018, 101, in press (accepted 9 Jan 2018)

[38] Owens D., Kendra P.E., Tabanca N., Narvaez T.I., Montgomery W.S., Schnell E.Q., Carrillo D. Quantitative analysis of contents and volatile emissions from $\alpha$-copaene and quercivorol lures, and longevity for attraction of Euwallacea nr. fornicatus in Florida. J. Pest Sci., 2018, doi: 10.1007/s10340-018-0960-6.

[39] Jacobson M., Uebel E.C., Lusby W.R., Waters R.M., Optical isomers of $\alpha$-copaene derived from several plant sources. J. Agric. Food Chem., 1987, 35, 798-800.

[40] Takeoka G., Flath R.A., Mon T.R., Buttery R.G., Teranishi R., Further applications of permethylated $\beta$-cyclodextrin capillary gas chromatographic columns. J. High Res. Chromatog., 1990, 13, 202-206.

[41] Hulcr J., Mann R., Stelinski L.L., The scent of a partner: Ambrosia beetles are attracted to volatiles from their fungal symbionts. J. Chem. Ecol., 2011, 37, 1374-1377.

[42] Kuhns E.H., Tribuiani Y., Martini X., Meyer W.L., Peña J., Hulcr J., Stelinski L.L., Volatiles from the symbiotic fungus Raffaelea lauricola are synergistic with manuka lures for increased capture of the redbay ambrosia beetle Xyleborus glabratus. Agric. For. Entomol., 2014, 16, 87-94.

[43] Miller D.R., Dodds K.J., Hoebeke E.R., Poland T.M., Willhite E.A., Variation in effects of conophthorin on catches of ambrosia beetles (Coleoptera: Curculionidae: Scolytinae) in ethanol- 
baited traps in the United States. J. Econ. Entomol., 2015, 108, 183-191.

[44] Owens D., Montgomery W.S., Narvaez T.I., Deyrup M.A., Kendra P.E., Evaluation of lure combinations containing essential oils and volatile spiroketals for detection of host-seeking Xyleborus glabratus (Coleoptera: Curculionidae: Scolytinae). J. Econ. Entomol., 2017, 110, 1596-1602.

[45] Gorzlancyk A.M., Held D.W., Ranger C.M., Barwary Z., Kim D., Capture of Cnestus mutilatus, Xylosandrus crassiusculus, and other Scolytinae (Coleoptera: Curculionidae) in response to green light emitting diodes, ethanol, and conophthorin. Florida Entomol., 2014, 97, 301-303.

[46] Mayfield III A.E., Brownie C., The redbay ambrosia beetle (Coleoptera: Curculionidae: Scolytinae) uses stem silhouette diameter as a visual host-finding cue. Environ. Entomol., 2013, 42, 743-750. 